\title{
Selective pathogenicity of murine rheumatoid factors of the cryoprecipitable IgG3 subclass
}

\author{
Thierry Berney, Thierry Fulpius, Takanori Shibata, Luc Reininger, \\ Jacques Van Snick', Hua Shan², Martin Weigert², Ann Marshak-Rothstein ${ }^{3}$, and \\ Shozo Izui \\ Department of Pathology, Centre Médical Universitaire, University of Geneva, 1211 Geneva 4, Switzerland \\ 'Ludwig Institute for Cancer Research, Brussels, Belgium \\ ${ }^{2}$ Institute for Cancer Research, Fox Chase Cancer Center, Philadelphia, PA 19111, USA \\ ${ }^{3}$ Department of Microbiology. Boston University Medical Center, Boston, MA 02118, USA
}

Key words: autoimmunity, glomerulonephritis, vasculitis, MRL-/pr/pr

\begin{abstract}
To analyze the involvement of rheumatold factors (RF) in the generation of cryoglobulins and the development of related tissue injuries, we have established a panel of antl-IgG2a RF mAbs derived from MRL/MpJ-Ipr/pr (MRL-Ipr), C3H/HeJ-Ipr/Ipr, and 129/Sv mice. After Injection of hybridoma cells to normal mice, all four IgG3 RF mAbs Induced cryoglobulinemia, and various degrees of glomerulonephritis and skin leukocytoclastic vasculitis. In contrast, none of the RF mAbs of the other lsotypes generated cryoglobulins or tissue lesions. Since the same observation was obtained with another panel of five clonally related anti-lgG2a RF mAbs of MRL-Ipr origin with almost Identical heavy and IIght chain varlable (V) reglons but five different Isotypes, It seems unlikely that the absence of pathogenicity of non-igG3 RF mAbs was due to differences in fine specificity or $V$ framework reglons. In addition, the analysis of serum RF in MRL-Ipr mice has demonstrated that a majority of 4 month old MRL-Ipr mice produced substantial amounts of IgG3 RF with cryoglobulln activity. Because the cryoglobulin actlvity is associated with the murine IgG3 heavy chain constant region, RF of this subclass may play a significant role in the development of autolmmune-related tissue injuries, especlally in MRL-Ipr mice.
\end{abstract}

\section{Introduction}

MRL/MpJ-/pr/pr (MRL-/pr) mice spontaneously develop a lupus-like autoimmune syndrome characterized by immunopathological manifestations such as necrotizing skin vasculitis and glomerulonephritis $(1,2)$. Remarkable features of this autoimmune syndrome include production of IgG rheumatoid factors (RF). responsible for the presence of intermediate-sized immune complexes $(3,4)$ similar to those found in the sera or synovial fluids of patients with rheumatoid arthritis $(5,6)$, and extremely large amounts of cryoglobulins with a marked enrichment of the lgG3 subclass (7).

Recently we have shown that an lgG3 anti-lgG2a RF mAb, 6-19, derived from MRL-Ipr mice is able to induce in normal mice glomerulonephritis and skin leukocytoclastic vasculitis in association with cryoglobulinemia $(8,9)$. To further extend this observation, we have analyzed if the association between RF and cryoglobulin activities was of importance in the generation of tissue injuries by studying the cryoprecipitability and pathogenicity of a panet of anti-IgG2a RF mAbs of various isotypes, obtained from unmanipulated MRL-tpr, $\mathrm{C} 3 \mathrm{H} / \mathrm{HeJ}-1 \mathrm{p} r / \mathrm{p} r(\mathrm{C} 3 \mathrm{H}-1 \mathrm{pr})$, and $129 / \mathrm{Sv}$ mice. Our results indicate that cryoprecipitable IgG3 is the only pathogenic isotype of anti-IgG2a RF mAbs, when injected into non-autoimmune mice, and that the majority of sera from MRL-Ipr mice exhibit RF of the lgG3 subclass with cryoglobulin activity.

\section{Methods}

Mlce

MRL-tpr, MRL-+1+, and CH3-tpr mice were purchased from the Jackson Laboratory. Bar Harbor, ME. BALB/c 
and C57BL/6 mice were otained from Harlan Olac Ltd, Oxfordshire, UK. (MRL $+1+\times B A L B / C) F_{1}(M R L \times B A L B)$ and $(\mathrm{C} 57 \mathrm{BL} / 6 \times \mathrm{BALB} / \mathrm{C}) \mathrm{F}_{1}(\mathrm{~B} 6 \times \mathrm{BALB})$ mice were bred in our own animal facilities. Only female mice were used in this study.

\section{Monoclonal RF}

One $\lg M$ (10-2), three IgG1 (AM6, AM7 and 6-2), one IgG2a (1-2D), five IgG2b (AM9, AM10, AM11, 2BE4, and 6-4), four IgG3 (6-19, AM16, 1-10B4, and 5-7B), and one IgA (46-52) anti-lgG2a RF mAbs were established from series of hybridomas from unimmunized MRL-Ipr or MRL-Ipr.lgh ${ }^{\theta}$ mice, as described previously $(8,10,11)$. An IgG3 anti-lgG2a RF mAb (48-10) was obtained from C3H-lpr mice (10). Six IgM anti-lgG2a RF mAbs (A6504C12, A6506C7, A6506G5, A6507A10, A5705B8, and $A 6605 E 10$ ) were derived from unmanipulated 129/Sv mice (12). Concentrations of $\lg M, \lg A$, and $\lg G$ subclasses in sera were determined by $\lg M, \lg A$, and $\lg G$ isotype and subclass-specific ELISA as described (13).

\section{In vivo treatment}

To study the pathogenicity of our panel of anti-lgG2a RF mAbs, Pristane-pretreated MRL $\times$ BALB or B6 $\times$ BALB mice were injected i.p. with $10^{7}$ hybridoma cells and killed when moribund (generally $7-12$ days after the implantation of hybridomas). In addition, BALB/c mice were injected i.p. with ascites containing $5 \mathrm{mg}$ of IgG3 anti-IgG2a RF mAbs and kulled after $18 \mathrm{~h}$. The macroscopic appearance of skin lesions was carefully noted. Blocks of ear skin and kidneys were obtaıned at autopsy and sections were stained with hematoxylin -eosin (HE) or periodicacid Schiff (PAS) for histopathological examination. Part of the kidneys were studied for glomerular deposition of IgG by direct staining with FITC-conjugated rabbit anti-mouse IgG (CappeLaboratories, Cochranville, PA).

\section{Sera and cryoglobulins}

Blood samples collected from the retro-orbital plexus were allowed to clot at $37^{\circ} \mathrm{C}$ for $2 \mathrm{~h}$. Sera were separated by centrifugation and placed in glass tubes at $4^{\circ} \mathrm{C}$ for 3 days. Then, sera were centrifuged at 3000 r.p.m. at $4^{\circ} \mathrm{C}$ for $10 \mathrm{~min}$. The supernatants were preserved, and the precipitates were washed five times with cold PBS ( $\mathrm{pH} \mathrm{7.4)}$ by centrifugation and finally resolubilized in $4 \mathrm{M}$ urea in the same volume as the original sample.

\section{Fluid-phase radioimmunoassay (RIA) for $R F$}

The RF activity was assessed by a RIA as described previously (8). Briefly, $50 \mu$ l of appropriately diluted serum samples was incubated with $50 \mu \mathrm{l}(1 \mu \mathrm{g})$ of ${ }^{125} \mathrm{I}$-labeled heat-aggregated polyctonal murine IgG (AMG) overnight at $4^{\circ} \mathrm{C}$. [ $\left.{ }^{125_{t}}\right]$ AMG, bound to RF, was precipitated and washed 3 times with PBS by centrifugation at $1880 \mathrm{~g}$ lor $5 \mathrm{~min}$ in a Beckman Microfuge 11 (Beckman Instruments Inc., Palo Alto, CA). The results are expressed as a percentage of [ ${ }^{125}$ ]]AMG precipitated. Studies on a panel of anti-lgG2a RF mAbs of different Ig isotypes have shown that only IgM and IgG3 RF mAbs efficiently precipitated [ ${ }^{125}$ ]]AMG (T.Shibata et al. Clin. Exp. Immunol.).

\section{ELISA for anti-IgG2a RF}

Ant1-IgG2a activities of RF mAbs were determined by ELISA as described previously $(9,10)$. In one study, microtiter plates were initially coated with $5 \mu \mathrm{g} / \mathrm{ml}$ of (4-hydroxy-3-iodo-5-nitropheny) acetyl (NIP)-conjugated BSA, and then with $1 \mu \mathrm{g} / \mathrm{ml}$ of $\operatorname{lgG} 2 \mathrm{a}, \lambda 1$ (NIP-23) anti-NIP mAb. Then, plates were incubated with appropriately diluted sera and the assay was developed with alkaline phosphatase-labeled rat anti-mouse $x$-chain mAb (H139.52.1). In another study, microtiter plates were coated with trinitrophenyl (TNP) - BSA, and subsequently incubated with $\mathrm{BALB} / \mathrm{c} \operatorname{lgG} 2 \mathrm{a}(\mathrm{Hy} 1.2)$ anti-TNP mAb (Igh-1 ${ }^{\text {a) }}$ ) or B6 IgG2a (C4010F4) anti-TNP mAb (lgh-1\%), prior to the addition of serum samples. The assay was developed with alkaline phosphataselabeled goat anti-mouse IgM or rabbit anti-lgG subclass-specific antibodies. For the detection of IgG2a anti-lgG2a RF activities, sera from MRL-Ipr mice (lgh-1) were incubated with plates coated with TNP and B6 IgG2a anti-TNP mAb (lgh-1\%), and the assay was developed with enzyme-labeled anti-lgG2a mAb $(\lg (1 \mathrm{a}) 8.3)$ which is reactive with $\operatorname{lgh}-11$, but not Igh-1b. Results are expressed as the OD value at $405 \mathrm{~nm}$.

\section{cDNA cloning and sequencing}

A cDNA library was produced from poly $(A)^{+}$RNA, prepared from 6-19 hybridoma, with oligo(dT) primer, and a recombinant plasmid, p6-19 clone 7.2, containing a full-length cDNA insert was isolated, as described previously (9). The nucleotide sequence corresponding to the 6-19 lgG3 heavy chain constant $\left(C_{\gamma} 3\right)$ region of the plasmid clone insert was determined by the dideoxynucleotide chain termınation method (14), using the Sequenase sequencing system (US Biochemical Corp., Cleveland, $\mathrm{OH})$ with $\left[\alpha^{-35}\right] \mathrm{S}$ ATP. The oligonucleotide primers were as follows $\left(5^{\prime}-3^{\prime}\right)$ : M13 sequencing primer (GTAAAACGACGGCCAGT), CH1 primers (GGATAGACAGATGG) complementary to codons $119-123$ and (GCTGAGGGAATAGAACCC) $(183$ - 188), CH2 primer (CCAGCTGACATGGACAT. CTGGG) (283 - 290), CH3 primer (GTTGGTGACCAGGCAGG) (389-394), and $3^{\prime}$ UT $C_{\gamma} 3$ primer (GACCCGAGGAATGGCTAGG). The oligonucleotide primers were synthesized with a System 1 Beckman (Fullerton, CA) DNA synthesizer. $V$ regions of 10-2 (lgM), 6-2 (lgG1), 1-2D (lgG2a), 6-2 (lgG2b), and 5-7B (IgG3) mAbs were sequenced from poly(A) + RNA as described previously (15). The $V$ region nucleotide sequences will be described elsewhere $(H$. Shan et al., manuscript in preparation).

\section{Results}

In vivo pathogenicity of anti-lgG2a RF mAbs of various isotypes We have previously demonstrated that the injection of an IgG3 anti-IgG2a RF mAb, 6-19, obtained from MRL-1pr mice induced in normal mice glomerulonephritis and skin leukocytoclastic vasculitis in association with cryoglobulinemia $(8,9)$. To further study the pathogenic activity of RF autoantibodies, a panel of anti-IgG2a RF mAbs of different isotypes, including three IgG3 anti-IgG2a RF mAbs, either from unmanipulated MRL-tpr, $\mathrm{C} 3 \mathrm{H}-1$ pr, or $129 / \mathrm{Sv}$ mice, were assessed for their pathogenic activity in relation to the generation of cryoglobulins.

All three IgG3 anti-lgG2a RF mAbs (AM16, 1-10B4, and 48-10) obtained from three series of hybridomas were cryoprecipitable, and each one of them was able to generate a characteristic vascular purpura of the skin of exposed parts (ears, tail, footpads) and an acute glomerulonephritis in MRL $\times$ BALB mice, similar to those found in mice receiving the 6-19 hybridoma (Table 1 
Table 1. Development of skin vasculitis and glomerulonephritis after injection of hybridomas secretıng lgG3 anti-lgG2a RF mAbs

\begin{tabular}{|c|c|c|c|c|c|}
\hline \multirow[t]{2}{*}{ Isotype } & \multirow[t]{2}{*}{$\mathrm{mAb}$} & \multirow[t]{2}{*}{$\lg ^{b}$} & \multirow[t]{2}{*}{ Cryoglobulins $^{c}$} & \multicolumn{2}{|l|}{ Lesions $^{d}$} \\
\hline & & & & Skin & Kidney \\
\hline $\lg M$ & $\begin{array}{l}\text { A6504C12 } \\
\text { A6506C7 } \\
\text { A6506G5 } \\
\text { A6507A 10 } \\
\text { A5705B8 } \\
\text { A6605E } 10\end{array}$ & $\begin{aligned} 7.4 & \pm 19 \\
13.1 & \pm 4.0 \\
26.2 & \pm 3.8 \\
425 & \pm 14.3 \\
27.6 & \pm 5.3 \\
43.0 & \pm 8.8\end{aligned}$ & $\begin{array}{l}<0.1 \\
<0.1 \\
<0.1 \\
<01 \\
<0.1 \\
<0.1\end{array}$ & $\begin{array}{l}0 / 4 \\
0 / 3 \\
0 / 3 \\
0 / 3 \\
0 / 4 \\
0 / 3\end{array}$ & $\begin{array}{l}0 / 4 \\
0 / 3 \\
0 / 3 \\
0 / 3 \\
0 / 4 \\
0 / 3\end{array}$ \\
\hline $\lg G 1$ & $\begin{array}{l}\text { AM6 } \\
\text { AM7 }\end{array}$ & $\begin{array}{r}11.8 \\
9.7\end{array}$ & $\begin{array}{l}<0.1 \\
<01\end{array}$ & $\begin{array}{l}0 / 1 \\
0 / 5\end{array}$ & $\begin{array}{l}0 / 1 \\
0 / 5\end{array}$ \\
\hline $\lg G 2 b$ & $\begin{array}{l}\text { AM9 } \\
\text { AM10 } \\
\text { AM11 } \\
2 B E 4\end{array}$ & $\begin{aligned} 2.7 & \pm 1.0 \\
18.1 & \pm 2.8 \\
2.3 & \pm 0.2 \\
11.1 & \pm 85\end{aligned}$ & $\begin{array}{l}<0.1 \\
<0.1 \\
<01 \\
<0.1\end{array}$ & $\begin{array}{l}0 / 3 \\
0 / 3 \\
0 / 3 \\
0 / 4\end{array}$ & $\begin{array}{l}0 / 3 \\
0 / 3 \\
0 / 3 \\
0 / 4\end{array}$ \\
\hline $\lg A$ & $46-42$ & $21.1 \pm 13.8$ & $<0.1$ & $0 / 5$ & $0 / 5$ \\
\hline $\lg \mathrm{G} 3$ & $\begin{array}{l}6-19 \\
\text { AM16 } \\
1 \cdot 10 B 4 \\
48-10\end{array}$ & $\begin{array}{r}4.8 \pm 1.1 \\
1.8 \pm 06 \\
12.0 \pm 38 \\
13.2 \pm 7.9\end{array}$ & $\begin{array}{l}21 \pm 9 \\
14 \pm 3 \\
55 \pm 31 \\
19 \pm 8\end{array}$ & $\begin{array}{l}8 / 8 \\
(3.6 \pm 0.7)^{d} \\
8 / 8 \\
(28 \pm 0.7) \\
2 / 5 \\
(1.2 \pm 1.6) \\
2 / 5 \\
(0.4 \pm 0.5)\end{array}$ & $\begin{array}{l}8 / 8 \\
(3.8 \pm 05)^{d} \\
8 / 8 \\
(1.9 \pm 10) \\
5 / 5 \\
(34 \pm 0.9) \\
3 / 5 \\
(16 \pm 1.5)\end{array}$ \\
\hline
\end{tabular}

${ }^{a}$ Hybridoma cells $\left(10^{7}\right.$ ) were inoculated i.p. into MRL $\times$ BALB (for hybridomas of MRL-and C3H-tpr ongins) or B6 $\times$ BALB (for hybridomas of $129 / \mathrm{SV}$ ongın) mice. Animals were killed 7-12 days later for serological and histological analysis.

bSerum levels of the lg isotype of the mAbs secreted by each hybridoma, expressed as $\mathrm{mg} / \mathrm{ml}$ (mean $\pm \mathrm{SD}$ ). Control values of each lg isotype were the following $\mathrm{lgM}, 0.2 \mathrm{mg} / \mathrm{ml} ; \mathrm{lgG} 1,1.1 \mathrm{mg} / \mathrm{ml} ; \mathrm{lgG} 2 \mathrm{a}, 38 \mathrm{mg} / \mathrm{ml}, \mathrm{lgG} 2 \mathrm{~b}, 05 \mathrm{mg} / \mathrm{ml} ; \mathrm{lgA}, 15 \mathrm{mg} / \mathrm{ml} ; \mathrm{lgG}, 0.1 \mathrm{mg} / \mathrm{ml}$

cSerum levels of cryoglobulins $(\mu \mathrm{g} / \mathrm{m})$ at death (mean $\pm \mathrm{SD}$ ). Note that cryoprecipitates isolated from sera of mice injected with lgG3 RF hybndomas were composed almost exclusively of lgG3.

$\mathrm{d}$ Incidence of macroscopically visble skin lesions and of glomenutonephritis None of the mice infected with non-lgG3 RF hybridoma cells developed significant skun or glomerular lesions. Semiquantitated values of skin and glomerular lesions induced by lgG3 RF mAbs on a 0 to $4+$ scale based on the intensity of each lesion are indicated in parentheses (mean \pm SD).

and Fig. 1). However, the severity and incidence of both tissue lesions varied in mice receiving different hybridoma: the 6-19 $\mathrm{mAb}$ was the most pathogenic $\mathrm{mAb}$, and the 48-10 mAb was the weakest. Although such differences could be in part related to the differences in the capacity of each hybridoma cell line to secrete IgG3 mAbs in vivo, the lack of correlation of the observed pathology with serum levels of each IgG3 RF mAb suggested that differences of pathogenicity were not solely related to differences of serum levels of each IgG3 mAb studied. This was further confirmed by the fact that there were significant differences in glomerular lgG deposits after the injection of ascites containing the same amount ( $5 \mathrm{mg}$ ) of each IgG3 anti-lgG2a RF mAb: the strongest IgG deposits were observed with the 6-19 and 1-10B4 mAbs, followed by the AM 16 mAb. Only minimal deposits were seen in mice receiving the $48-10 \mathrm{mAb}$.

The observed differences in nephritogenicity of the various IgG3 RF mAbs were not apparently due to an abnormality of the $\mathrm{C}_{\gamma} 3$ region, because the nucleotide sequence analysis of the 6-19 cDNA clone did not demonstrate any mutation in its $\mathrm{C}_{\gamma} 3$ region, whose nucleotide sequence is identical to the published BALB/c IgG3 germline sequence (16) (data not shown). However, the 6-19 cDNA clone, and also other IgG3 mAbs derived from BALB/c, C57BL/6, 129/Sv, and MRL mouse strains (unpublished data), were found to contain an additional codon (GCT encoding an alanine), which is present in the BALB/c germline sequence $5^{\prime}$ to the expected splice site (codon 114).
In contrast to the remarkable pathogenic activity of all IgG3 RF mAbs, no RF mAb from any Ig isotype (IgM, IgG1, IgG2b, or $\lg A$ ) studied other than IgG3 was able to cryoprecipitate and to elıcit either skin or glomerular lesions in any sıngle mouse (Table 1). This was not due to low circulating levels of the mAbs secreted by the hybridomas, as serum Ig levels were significantly enriched in the isotype of the mAbs secreted by each hybridoma.

\section{Pathogenicity of different isotypes of clonally related anti-lgG2a RF mAbs}

To rule out the possibility that the observed isotype-related differences in pathogenicity are due to differences in fine specificities or framework regions (FR) of the $V$ domains, we have established another panel of anti-lgG2a RF mAbs from one single unmanipulated MRL-1pr mouse and selected five clonally related RF mAbs of various isotypes ( $\mathrm{gM}, \lg \mathrm{g} 1, \lg G 2 a, \lg G 2 b$, and IgG3) exhibiting almost identical $V_{H}$ and $V_{L}$ nucleotide sequences. In fact, there was a maximum of six amino acid differences in each $V$ region between the 5-7B IgG3 anti-lgG2a RF $m A b$ and the mAbs of the other isotypes (Table 2).

When their pathogenicity was studied by injecting MRL $\times$ BALB mice i.p. with hybridoma cells secreting these mAbs, the 5-7B IgG3 RF mAb was again the only one able to cryoprecipitate and to generate the characteristic skin and glomerular tesions. In contrast, 10-2 (IgM), 6-2 (lgG1), 1-2D (IgG2a), and 6-4 (lgG2b) mAbs induced neither cryoglobulinemia nor significant 

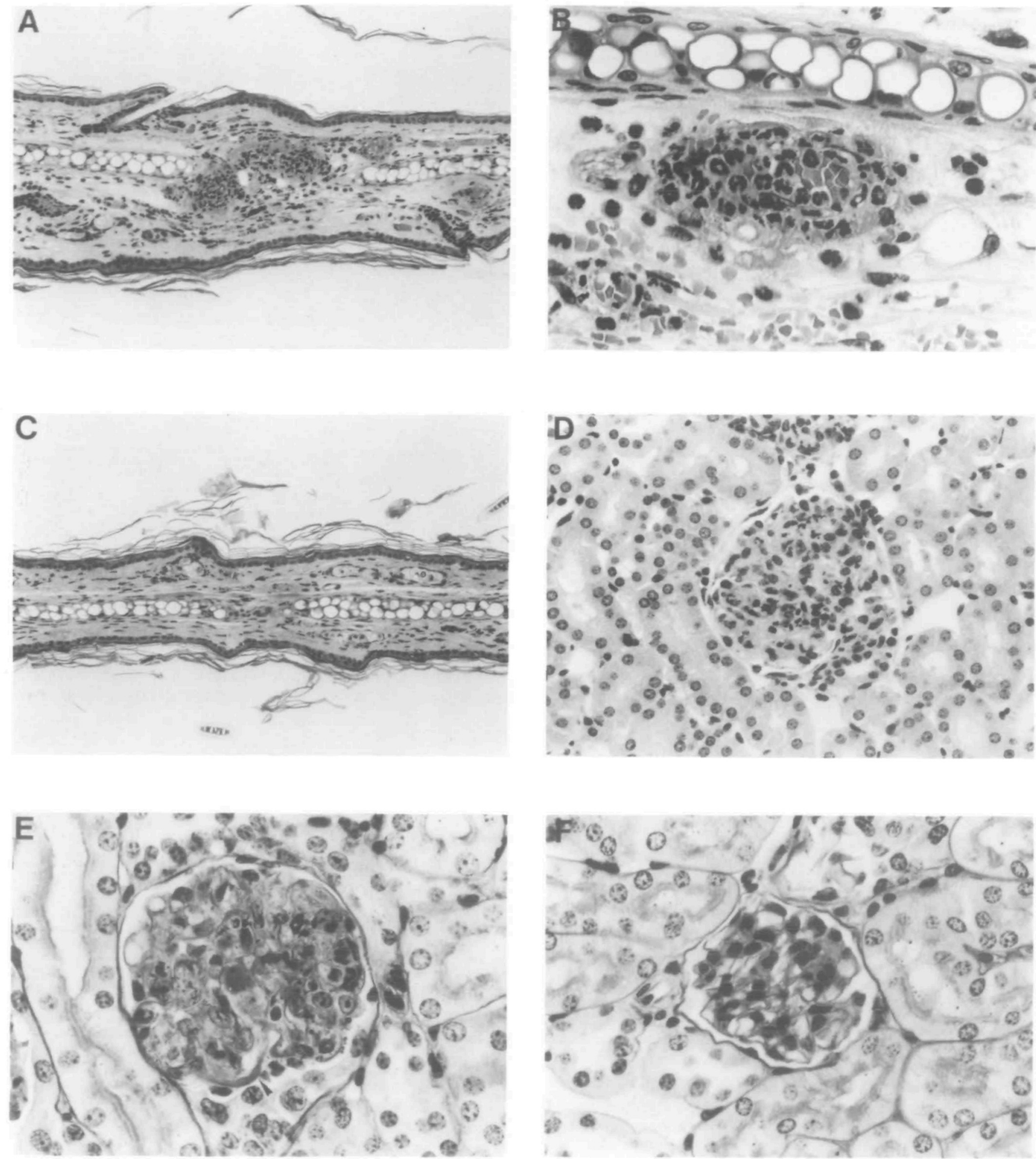

Fig. 1. (A) and (B) Representative histological appearance of skin lesions of ears 10 days after the i p. injection of AM16 IgG3 RF hybndoma cells into MRL $\times$ BALB mice. Leukocytoclastic vasculitis was characterized by the infiltration of polymorphonuclear leukocytes and the extravasation of erythrocytes. (HE; A: $\times 60 ; \mathrm{B}: \times 240$ ) (C) Absence of leukocyloclastic vascular lesions in skin of ears from mice injected with hybridoma cells secreting the 1-2D lgG2a RF mAb. (HE; $\times 60$.) (D) and $(E)$ Representative histological appearance of glomerular lesions induced by the AM16 IgG3 RF mAb showing the proliferative and exudative changes (D) and the deposition of PAS-positive material along the glomerular capillary walls (E, arrows) Note a marked enlargement of glomeruli as compared with those (F) from mice injected with non-pathogenic 1-2D igG2a RF hybridoma cells. (D: $\mathrm{HE}, \times 120$; E: PAS, $\times 240$.) (F) Representative histological appearance of kidneys after the i.p. injection of 1-2D lgG2a RF hybridoma cells. Note the absence of significant glomerular changes. (PAS, $\times 240$.) 
tissue lesions of any kind, in spite of marked enrichment of the corresponding $\mathrm{lg}$ isotype for each $\mathrm{mAb}$ injected and of comparable or even higher activitıes of anti-IgG2a RF in the circulating blood (Table 3).

\section{Cryoglobulin activities of RF in sera from MRL-Ipr mice}

Since our studies on a panel of anti-lgG2a RF mAbs have demonstrated that their pathogenic activity is associated with IgG3 cryoglobulin activity, we have investigated the extent of cryoglobulin and RF association in MRL-Ipr mice. To study this, RF activities in whole sera and in sera depleted of cryoglobulins from 4 month old MRL-1pr mice were assessed by fluid-phase RIA, which efficiently detects IgM and IgG3 classes of RF. RF activities markedly diminished in the majority of sera after removal of cryoglobulins (Fig. 2). In fact, mean values of [ ${ }^{125}$ I]AMG precipitating activities by $10 \mu \mathrm{l}$ of sera dropped from $49.9 \pm 12.3$ to $16.8 \pm 16.5 \%$. Quantitative studies by serial dilution of sera showed that 18 of 20 samples from 4 month old MRL-tpr mice exhibited a $>50 \%$ decrease in RF activities detectable by RIA after cryoglobulin elimination. When Ig isotypes of anti-lgG2a RF were analyzed by ELISA, in four out of five mice tested, only the

Table 2. Differences in the amino acid sequences of four anti-IgG2a RF mAbs clonally related to the IgG3 5-7B RF mAb

\begin{tabular}{llll}
\hline mAb & Isoptype & $V_{H}$ & $V_{L}$ \\
\hline $10-2$ & $\lg M$ & $0^{b}$ & $1^{b}$ \\
& & - & $C D R 1^{c}$ \\
$6-2$ & $\operatorname{lgG} 1$ & 6 & 1 \\
& & $C D R 1, C D R 2, F R 1, F R 2$ & $C D R 1$ \\
$1-2 D$ & $\lg 2 a$ & 4 & 4 \\
& & $C D R 1, C D R 2, F R 2$ & $C D R 1, C D R 2, C D R 3$ \\
$6-4$ & $\operatorname{lgG} 2 b$ & 1 & 4 \\
& & $C D R 2$ & $C D R 1, C D R 3$ \\
\hline
\end{tabular}

av region amıno acid sequences were deduced from the nucleotide sequences of mRNA encoding $V_{H}$ and $V_{x}$ regions of anti-lgG2a RF mabs.

Number of amino acid substitutions in comparison with the corresponding $V$ regions of the 5-7B IgG3 anti-lgG2a RF mAb.

Location of amıno acid substitutions in comparison with the corresponding $V$ regions on the 5-7B lgG3 anti-lgG2a RF mAb.
IgG3 subclass was selectively diminished in RF after removal of cryoglobulins from the sera of MRL-tpr mice. Representative results are shown in Fig. 3. This indicated that lgG3 RF were indeed associated with cryoglobulins in MRL-tpr mice.

\section{Dlscussion}

In the present study, using a panet of anti-IgG2a RF mAbs derived either from unmanipulated MRL $/ p r, C 3 H-1 p r$, or 129/Sv mice, we have demonstrated that only RF mAbs that are able to cryoprecipitate-all from the IgG3 subclass-can induce skin vasculitis and glomerulonephritis. Furthermore, we have shown that substantial amounts of cryoprecipitable IgG3 RF actuvities were detected in lupus-prone MRL-/pr mice.

The notion that Ig cryoprecipitability, which is associated with the IgG3 subclass, can promote the pathogenic activity of RF autoantibodies is strongly suggested by our observation that all five cryoprecipitable IgG3 ant/-lgG2a RF mAbs tested, derived from five different series of hybridomas of MRL- and C3H-lpr origins, are able to induce severe skin vascular lesions and glomerulonephritis in normal mice, whereas no RF of the same specificity but of a different $\mathrm{Ig}$ isotype lacking the cryoglobulin activity can provoke such lesions. It is unlikely that differences in fine specificities or FR sequences of the $V$ region may account for the absence of pathogenicity observed with RF mAbs of Ig isotypes other than IgG3. In fact, in a panel of anti-lgG2a RF mAbs of five different isotypes (IgM, IgG1, IgG2a, IgG2b, and IgG3), apparently from the same clonal origin with almost identical $V$ region sequences, the IgG3 $R F$ mAb was again the only one able to generate cryoglobulins and tissue lesions.

The lesions observed in mice injected with lgG3 RF mAbs were similar to one another and have already been described in previous studies for one of these mAbs, clone $6-19(8,9)$. However, there exists some individual variability in the extent to which each IgG3 RF mAb induces skin vasculitis or glomerulonephritis, some mAbs being more pathogenic for glomerular and/or vascular lesions than others. At present, we do not have a good explanation for these differences. However, since RF activity appears to be critically involved in the generation of leukocytoclastic vasculitis induced by the lgG3 RF mAbs (9),

Table 3. Pathogenicity of different isotypes of five clonally related anti-lgG2a RF mAbs

\begin{tabular}{|c|c|c|c|c|c|c|}
\hline \multirow[t]{2}{*}{ Isotype } & \multirow[t]{2}{*}{$\mathrm{mAb}$} & \multirow[t]{2}{*}{$19^{b}$} & \multirow[t]{2}{*}{$\mathrm{RF}^{\mathrm{c}}$} & \multirow[t]{2}{*}{ Cryoglobulins $^{d}$} & \multicolumn{2}{|l|}{ Lesions $^{e}$} \\
\hline & & & & & Skin & Kidney \\
\hline $\begin{array}{l}\text { IgM } \\
\lg G 1 \\
\operatorname{lgG} 2 a \\
\operatorname{lgG} 2 b \\
\lg G 3\end{array}$ & $\begin{array}{l}10-2 \\
6-2 \\
1 \cdot 2 D \\
6-4 \\
5-7 B\end{array}$ & $\begin{array}{r}16.9 \pm 4.9 \\
8.5 \pm 10 \\
158 \pm 7.2 \\
16.6 \pm 2.0 \\
6.1 \pm 1.7\end{array}$ & $\begin{array}{l}>2.000 \\
1.394 \pm 0.161 \\
0.774 \pm 0.535 \\
1.484 \pm 0.155 \\
0.933 \pm 0.137\end{array}$ & $\begin{array}{l}<0.1 \\
<0.1 \\
<0.1 \\
<0.1 \\
29 \pm 10\end{array}$ & $\begin{array}{l}0 / 4 \\
0 / 5 \\
0 / 5 \\
0 / 3 \\
5 / 7 \\
(1.7 \pm 1.4)^{\circ}\end{array}$ & $\begin{array}{l}0 / 4 \\
0 / 5 \\
0 / 5 \\
0 / 3 \\
7 / 7 \\
(3.9 \pm 0.4)^{\circ}\end{array}$ \\
\hline
\end{tabular}

a Hybridoma cells $\left(10^{7}\right)$ were inoculated i.p. into MRL $\times$ BALB mice. Animals were killed $7-12$ days later for serotogical and histological analysis.

See Table 1.

'Serum anti-IgG2a RF activities were determined by ELISA. Microtiter plates coated with NIP - BSA and IgG2a anti-NIP mAb (NIP-23) were incubated with serum samples at a 1:25,000 dilution, and the assay was developed with alkaline phosphatase-labeled rat anti-mouse $x$-chain mAb (H139.52.1). Results are expressed as the $O D$ value al $405 \mathrm{~nm}$. Control values at a 1:1000 dilution prior to the hybridoma injection were $0.055 \pm 0.010$ (mean of five mice $\pm \mathrm{SD}$ ).

dSee Table 1.

See Table 1. 
differences in pathogenic potential of each IgG3 RF mAb may be in part related to possible differences of affinity of RF autoantibodies. In addition, it should be noted that atthough the nephritogenic activity of the 6-19 RF mAb is apparently determined only by its cryoglobulin activity ( $(9)$, serum levels of cryoglobulins in mice receiving different lgG3 RF mAbs did not correlate well with the severity of glomerular lesions and not all IgG3 cryoglobulins lacking RF activity were able to induce glomerular lesions (8.17). This suggests that qualitative features, such as conformation and/or temperature dependency, of cryoglobulins may be critical in the nephritogenic activity of IgG3 cryoglobulins. Since we did not find any mutations in the $\mathrm{C}_{\gamma} 3$ region of the most pathogenic 6-19 mAb, $V$ region sequences are likely to determine the pathogenicity of lgG3 cryoglobulins. In this context, it should be mentioned that the electrostatic charges in the $V$ regions can markedly influence the cryoglobulın activity of $\lg G 3$ (18). Accordingly, the introduction of new charged amino acid residues as a result of somatic mutations occurring during the course of autoimmune responses, as shown in the case of anti-DNA antibodies for MRL-tpr mice (19), may create more pathogenic cryogeneratıng autoantibodies.

The selective pathogenicity of RF mAb of the cryoprecipitable IgG3 subclass is significant, because cryoglobulins have long been suggested to be a potential source of tissue injuries in systemic lupus erythematosus, rheumatold arthritis, and related autoimmune diseases (20). Extensive light and electron microscopic studies have shown that glomerular lesions induced by the 6-19 IgG3 RF mAb resemble 'wire-loop' lesions, i.e. subendothelial accumulation of electron-dense deposits, characteristically described for lupus nephritis (17). In addition to IgG3 RF mAbs, we have recently observed that an IgG3 anti-DNA mAb derived from $(N Z B \times N Z W) F_{1}$ hybrid mice is able to induce similar glomerular lesions (17). Thus, IgG3 autoantibodies with cryoglobulin activity, independently of their immunological specificities, may participate in the pathogenesis of lupus nephritis. In fact, recent studies on MRL-fpr and

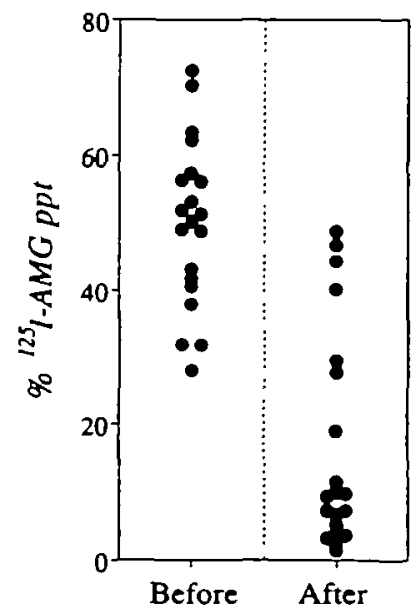

Flg. 2. Comparison of serum RF actuvities before and after removal of cryoglobulins in 4 month ofd MRL tpr mice. Whote sera or sera depleted of cryoglobulin $(10 \mu)$ were incubated with $1 \mu \mathrm{g}$ of [ ${ }^{125}$ ] $]$ AMG at $4^{\circ} \mathrm{C}$ overnight. Results are expressed as percent precipitation of [ ${ }^{125}$ ]]AMG.
MRL-1pr $\times(\mathrm{MRL}-1 p r \times \mathrm{CH} 3-1 p r)$ backcross mice have shown a good correlation of IgG3 production with the development of glomerular lesions, and selective enrichment of IgG3 in renal eluates from diseased kidneys (21). The pathogenic importance of IgG3 cryoglobulins can be further supported by the fact that the transfer of the xid gene, which causes a defect of $\operatorname{lgM}$ and IgG3 production, delayed the development of lupus nephritis in autoimmune mice including MRL $\downarrow p r$ mice (22). Finally, it should be mentioned that all human IgG3 myeloma proteins studied by Capra and Kunket (23) undergo a concentration- and temperature-dependent aggregation, and that some IgG3 myeloma proteins with RF activity are indeed able to generate cryoglobulins $(24,25)$. The detection of IgG3 RF in relation to cryoglobulin activity may be a useful and predictive indicator of the course of seropositive rheumatoid arthritis.
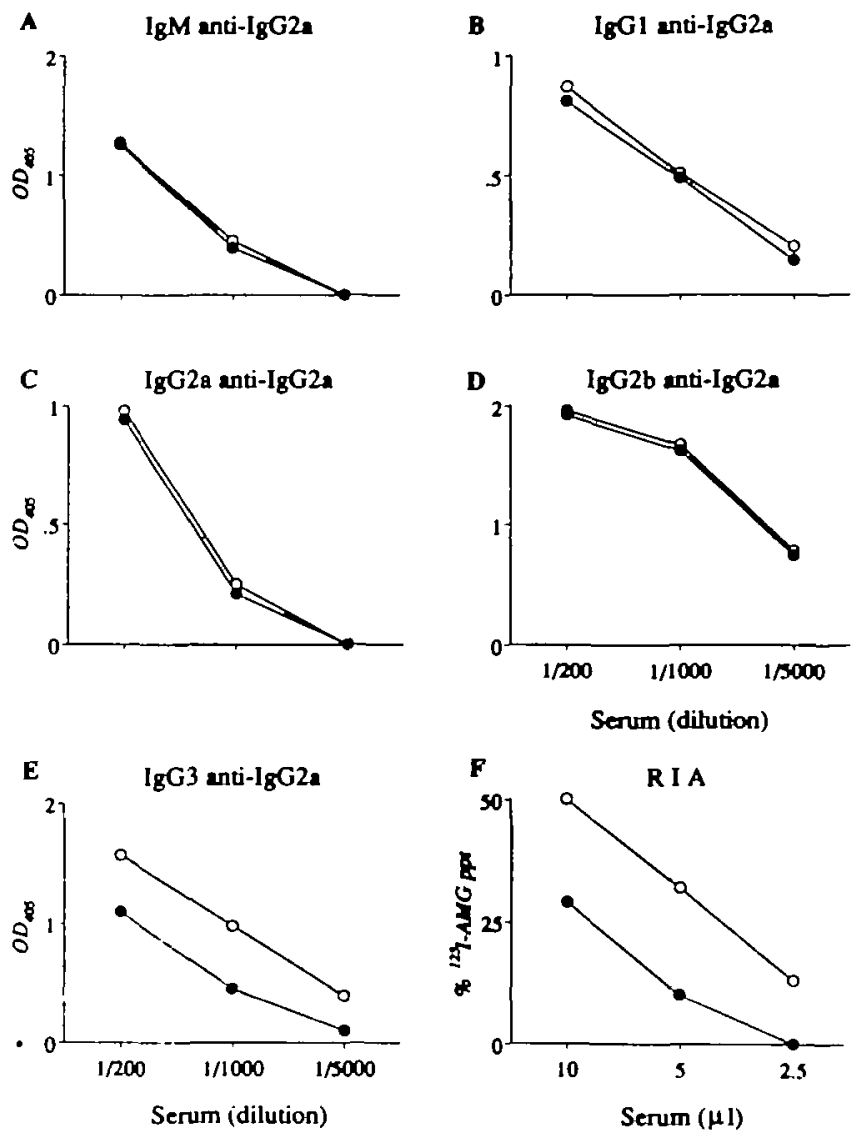

Fig. 3. Comparison of serum ant-lgG2a RF activities before $(O)$ and after (-) removal of cryoglobulins from a 4 month old MRL-tpr mouse. (A), (B), (D), and (E): microtiter plates coated with TNP - BSA and IgG2a anti-TNP mAb (Hy 1.2) (lgh-1 $\left.{ }^{2}\right)$ were incubated with serially diluted serum samples, and the assay was devetoped with alkaline phosphataselabeled goat anti-mouse IgM or rabbit anti-lgG1, IgG2b, or IgG3 antibodies. (C): microtiter plates coated with TNP - BSA and IgG2a anti-TNP (C4010F4) $(\operatorname{lgh}-1$ b) were incubated with serum samples, and the assay was developed with enzyme-labeled anti-lgG2a mAb $(\lg (1 \mathrm{a}) 8.3)$ which is reactive with IgG2a of MRL-tpr mice (lgh-1), but not with IgG2a of the lgh- ${ }^{b}$ allotype. Results of ELISA $(A-E)$ are expressed as the OD value at $405 \mathrm{~nm}$. (F): Huid-phase RIA Vanous amounts of whole sera or sera depleted of cryoglobulins were incubated with $1 \mu \mathrm{g}$ of [ ${ }^{125}$ ]]AMG at $4^{\circ} \mathrm{C}$ overnight. Results are expressed as percent precipitation of [125|]AMG. 


\section{Acknowledgements}

This work was supported by grant $31-28782.90$ from the Swiss National Foundation for Scientific Research to S. I.; by USPHS grants AR-35230 and AR-01684 to A. M.-R.; by grant GM-20964 from the National Institutes of Heatth to M. W.; by the Swiss Confederation acting on the proposal of the 'Commission Féderale des Maladies Rhumatismales'; and by the Roche Research Foundation. M. W. is a recipient of a Sheryl N. Hirsch Award from the Lupus Foundation of Philadelphia. We thank Ms Martine Detraz, Genevève Leyvraz, and Joan Stalder for excellent technical help.

\section{Abbreviatlons}

\begin{tabular}{|c|c|}
\hline $\begin{array}{l}\text { AMG } \\
\text { B6 } \times \text { BALB } \\
\text { C3H- } 1 p r \\
\text { FR } \\
\text { HE } \\
\text { MRL-Ipr } \\
\text { MRL } \times \text { BALB } \\
\text { NIP } \\
\text { PAS } \\
\text { RF } \\
\text { RIA } \\
\text { TNP }\end{array}$ & 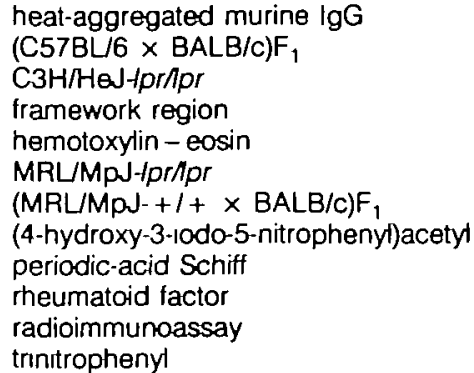 \\
\hline
\end{tabular}

\section{References}

1 Murphy, E. D and Roths, J B. 1978. Autoimmunity and lymphoprolfferation induction by mutant gene $/ p r$, and acceleration by a male-associated factor in strain BXSB mice. In Rose, N. R. Bigaze, P E., and Warner, N. L., eds, Genetic Control of Autammune Disease, p. 207. Elsevier/North Holland, New York.

2 Andrews, B. S., Eisenberg, R A., Theofilopoulos, A. N., Izui, S. Wilson, C. B., McConahey, P. J., Murphy, E. D., Roths, J. B., and Dixon, F J. 1978. Spontaneous murine lupus like syndromes: clinical and immunopathological manifestations in several strains. J. Exp. Med. 148.1198

3 Eisenberg, R. A, Thor, L. T., and Dixon, F. J. 1979. Serum-serum interactions in autoimmune mice Arthritis Rheum. 22:1074.

4 Izui, S. and Ersenberg. R. A. 1980 Circulating anti-DNA - heumatoid factor complexes in MRL1 mice. Clin. Immund. Immunopathot. 15.536

5 Kunkel, H. G., Müller-Eberhard, H. M., Fudenberg, H. H., and Tomasi, T. B. 1961. Gamma globulin complexes in meumatoid arthrits and certain other conditions. J. Clin. Invest. 40:117

6 Winchester, R. J., Kunkel, H. G., and Agnello, V. 1970. Gamma globulin complexes in synovial fluids of patients with rheumatoid arthrits. Partial characterization and relationship to lowered complement levels. Clin. Exp Immunot. 6.689.

7 Abdelmoula, M., Spertini, F., Shibata, T., Gyotoku, Y., Luzuy, S., Lambert, P. H., and Izui, S. 1989. IgG3 is the major source of cryoglobulins in mice. J. Immunal. 143:526.

8 Gyotoku, Y., Abdelmoula, M., Spertini, F., Izui, S., and Lambert, P. H. 1987. Cryoglobulinemı induced by monoctonal immunoglobulin $G$ heumatoid factors derived from autoimmune MRLMPJ-fpr/pr mice. J. Immunol. 138:3785.

9 Reininger, L., Berney, T., Shibata, T., Spertıni, F., Merino, R., and Izui, S. 1990. Cryoglobulinemia induced by a murine lgG3 meumatoid factor: skin vasculitis and glomerulonephritis arise from distinct pathogenic mechanisms. Proc. Natl Acad. Sci. USA 87:10038.

10 Wollowicz, C. B., Sakorafas, P., Rothstein, T. L., and MarshakRothstein, A. 1988. Oligoctonality of meumatoid factors arising spontaneously in /pripr mice. Clin. Immund. Immunopathol. 46:382.

11 Shlomchik, M. J., Marshak-Rothstein, A., Wolfowicz, C. B., Rothstein, T. L., and Weigert, M. G. 1987. The role of ctonal selection and somatic mutation in autoimmunity. Nature 328.805.

12 Van Snick, J L, Stassin, V., and de Lestré, B. 1983 Isotypic and allotypic specificity of mouse rheumatoid factor. J. Exp. Med 157:1006.

13 Luzuy, S., Merino, J., Engers, H., Izui, S., and Lambert, P. H. 1986. Autormmunity after induction of neonatal tolerance to alloantigens. role of $\mathrm{B}$ cell chımensm and $\mathrm{F} 1$ donor $\mathrm{B}$ cell activation. J. Immunol. $136 \cdot 4420$

14 Sanger, F. S. Nicklen, S. and Coulson, A. R 1977. DNA sequencing with chain terminatung inhibitors. Proc. Natt Acad. Sci. USA 74.5463

15 Shlomchık, M. J., Nemazee, D. A., Sato, V. L., Van Snick, J., Carson, D. A., and Weigert, M. G. 1986. Variable regıon sequences of murine $\lg M$ and $\lg G$ monoclonal antibodies (meumatoid factors). a siructural explanation for the high frequency of $\lg M$ anti-lgG $1 \mathrm{~B}$ cells J. Exp. Med. 164:407.

16 Wels, J. A., Word, C J., Rimm, D., Der-Balan, G. P., Martinez, H. M., Tucker, P. W., and Blattner, F R. 1984. Structural analysis of the murine $\lg$ G3 constant region gene. EMBO J. 3.2041

17 Lemoıne, R., Berney, T., Shibata, T., Fulpius, T., Gyotoku, Y., Shımada, H., Sawada, S, and Izui, S. 1992. Induction of 'wire-loop' lesions by murne monoctonal IgG3 cryoglobulins. Kıdney Int. 41: in press.

18 Spertini, F., Coulie, P. G., Van Snick, J , Davidson, E., Lambert, P.H., and Izui, S. 1989. Inhıbition of cryoprecipitation of murıne IgG3 anti-dinitrophenyl (DNP) monoclonal antibodies by anionic DNP - amino acid conjugates. Eur. J. Immunol. 19:273.

19 Shlomchik, M, Mascelli, M., Shan, H., Radic, M. Z, Pisetsky, D., Marshak-Rothstein, A., and Weigert, M. 1990. Anti-DNA antibodies from autoimmune mice arise by clonal expansion and somatic mutation. J. Exp. Med. 171:265.

20 Brouet, J C., Clauved, J. P., Danon, F., Klein, M., and Seligmann, M. 1974. Biologic and clinical significance of cryoglobulins. A report of 86 cases Am. J Med 57.775.

21 Takahashi, S., Nose, M., Sasaki, J., Yamamoto, T., and Kyogoku, M 1991. IgG3 production in MRL tpr mice is responsible for devetopment of lupus nephritis. J. Immunal. 147:515.

22 Steinberg, E. B., Santoro, T. J., Chused, T.M., Smathers, P. A., and Steinberg. A. D. 1983. Studies of congenic MRL-tpr/pr.xid mice. J. Immunol. 131:2789.

23 Capra, J. D. and Kunket, H. G. 1970. Aggregation of $\gamma$ G3 proteins: relevance to the hyperviscosity syndrome. J. Clin. Invest. 49:610.

24 Grey, H. M., Kohler, P. F., Terry, W. D., and Franklin, E. C. 1968. Human monoclonal $\gamma \mathrm{G}$-cryoglobulins with anti- $\gamma$-globulin activity. $J$. Clin. Invest. 47:1875.

24 Saluk, P. H. and Clem, W. 1975. Studies on the cryoprecipitation of a human IgG3 cryoglobulin: the effect of temperature-induced conformational changes on the primary interaction. Immunochemistry 12:29. 